\title{
Standards, Standards: Where might you be?
}

\author{
Kari A. Kozak, University of Iowa
}

\begin{abstract}
Getting access to standards can prove to be a tricky and expensive endeavor. The Lichtenberger Engineering Library at the University of Iowa has been working to try and simplify the process in order to provide a greater depth of available standards for free to students, faculty, and staff.
\end{abstract}

Finding and accessing standards can be a complex task since there are hundreds of agencies or organizations that produce standards, with each one having their own set of rules and regulations on how they can be viewed and distributed. There is unfortunately no one place that lists all existing standards. A student often needs to search multiple databases or indexes to fully see what is available in their area of study. Once they find the standards they are looking for, it is time to actually find access to the full text. Standards often cannot be requested through loans from other libraries due to copyright restrictions, which makes the process all that more complicated. They also are not regularly listed in library catalogs since they are so hard to catalog and change frequently.

Over the last couple of years, the Library has worked to provide electronic access to as many standards as possible, and to educate the students about the availability of standards in the library. The Library has access to an online database called TechStreet that provides access to standards by 48 different publishers and has searchable abstracts for others. It is still not all inclusive, but it is getting better. There is also electronic access to over half a dozen individual agencies or organizations standards through separate subscriptions. For those standards that are not part of any electronic packages, the library orders them in print to be housed in the Library.

To help with the complexity of searching and accessing these standards, the librarian visits various classes each semester to give an overview of what standards are, as well as providing instruction on gaining access to individual standards. These sessions, along with projects assigned in the courses, help students gain an understanding of the importance of standards in industry today.

\section{Introduction}

Standards are a unique type of resource that can prove to be very difficult for engineering students, faculty, and staff to access as well as for libraries to maintain. Standards are defined as documents that stipulate or recommends: 1. Minimum levels of performance and quality of goods and services. 2 . Optimal conditions and procedures for operations in science, industry, and commerce; including production, evaluation, distribution, and utilization of materials, products, and services. ${ }^{1}$ Different types of standards that exist include: 1. Category, type, dimension, structure, equipment, quality, grade, 
performance, durability, or safety. 2. Methods of manufacturing, drawing, designing, operating. 3. Methods of testing, analyzing, appraising, verifying, or measuring. 4. Terms, abbreviations, symbols, marks, preferred number.

Standards can be produced by many different agencies, organizations, and government bodies which requires the user to know which issuing bodies are most relevant to them based on their area of study and research. This requires faculty, students, and researchers to do comprehensive searches and have an understanding of where to search for standards and also where they might be able to access them.

Unfortunately, standards are not all searchable in just one database. There are a few databases that come close but they are not all-inclusive.

Since this is not always a simple process, the Library has to provide broad instruction and outreach on what standards are, how to search for them, and how to access them. The Library also tries to maintain a healthy collection of standards. Since many standards cannot be loaned out from other libraries due to copyright, the library works to provide access to a diverse variety of standards.

\section{Standards in the Library}

Over the last couple years, the Lichtenberger Engineering Library has been working to increase access to standards, focusing an electronic access. Before this time most standards were only available in print format. These standards were not cataloged so a user would need to visit the library and ask the library staff which standards were currently available.

The first project was to have a print record of what standards we currently had available in print. This list allowed for the library staff to quickly checking what standards were available and what we needed to order.

The second project was to convert as many standards as possible to electronic format. Due to budget constraints, this process was completed over time in various steps. The first step was to transition as many of the standards currently in print to electronic format through a subscription database platform called TechStreet. TechStreet was chosen due to it allowing for purchase of individual standards that did not require expensive packages. It also allowed for unlimited uses of each standards purchased as well as access to historic and redline versions of the standards. The library could also add standards continuously throughout the year when requested and the standard would be available within one to two business days. Standards were now available from 48 publishers including International Organization of Standards (ISO), American National Standards Institute (ANSI), British Standards Institute (BSI), ASHRAE (formerly the American Society of Heating, Refrigerating, and Air Conditioning Engineers), American Society of Mechanical Engineers (ASME), American Water Works Association (AWWA), National Fluid Power Association (NFPA (Fluid)), and Accredited Standards Committee X9, Inc (X9). 
After purchasing TechStreet, the Library began to look at how to gain access to a variety of standards not available through this database. The library already had access to ASTM standards electronically but over the course of the last year added access to American Society of Civil Engineers (ASCE) standards. Table 1 lists all 90 agencies/organizations' standards that the Library currently has available.

\begin{tabular}{|c|c|c|c|}
\hline \multicolumn{4}{|c|}{ Standards } \\
\hline Organization & \# of Papers & Located at: & Format \\
\hline $\begin{array}{l}\text { AAMI (Association for the } \\
\text { Advancement of Medical } \\
\text { Instrumentation) }\end{array}$ & 8 & TechStreet & Online \\
\hline ABA (Architectural Barriers Act) & 1 & & Print \\
\hline $\begin{array}{l}\text { ABMA (American Bearing } \\
\text { Manufacturers Association) }\end{array}$ & 29 & TechStreet & Online \\
\hline ACI (American Concrete Institute) & 1 & & Print \\
\hline $\begin{array}{c}\text { ADA (American Dental } \\
\text { Association) }\end{array}$ & 2 & TechStreet & Online \\
\hline AGA (American Gas Association) & 7 & TechStreet & Online \\
\hline $\begin{array}{c}\text { AGMA (American Gear } \\
\text { Manufacturers Association) }\end{array}$ & 20 & & Print \\
\hline $\begin{array}{l}\text { AHAM (Association of Home } \\
\text { Appliance Manufacturers) }\end{array}$ & 1 & TechStreet & Online \\
\hline $\begin{array}{l}\text { AIAA (American Institute of } \\
\text { Aeronautics and Astronautics) }\end{array}$ & 5 & TechStreet & Online \\
\hline $\begin{array}{l}\text { AIIM (Association for Information } \\
\text { and Image Management) }\end{array}$ & 109 & TechStreet & Online \\
\hline $\begin{array}{l}\text { AIM (Association for Automatic } \\
\text { Identification and Mobility) }\end{array}$ & 4 & & Print \\
\hline ANS (American Nuclear Society) & 1 & & Print \\
\hline ANS (American Nuclear Society) & 15 & TechStreet & Online \\
\hline $\begin{array}{l}\text { ANSI (American National } \\
\text { Standards Institute) }\end{array}$ & 280 & & Print \\
\hline $\begin{array}{l}\text { ANSI (American National } \\
\text { Standards Institute) }\end{array}$ & 32 & TechStreet & Online \\
\hline $\begin{array}{c}\text { API (American Petroleum } \\
\text { Institute) }\end{array}$ & 10 & TechStreet & Online \\
\hline $\begin{array}{c}\text { APSP (Association of Pool \& Spa } \\
\text { Professionals) }\end{array}$ & 1 & & Print \\
\hline $\begin{array}{c}\text { AS (Australian Steel } \\
\text { Specifications) } \\
\end{array}$ & 3 & & Print \\
\hline $\begin{array}{c}\text { ASA (Acoustical Society of } \\
\text { America) }\end{array}$ & 48 & TechStreet & Online \\
\hline $\begin{array}{c}\text { ASABE (American Society of } \\
\text { Agricultural and Biological } \\
\text { Engineers) }\end{array}$ & 255 & ASABE Technical Library & Online \\
\hline $\begin{array}{l}\text { ASCE (American Society of Civil } \\
\text { Engineers) }\end{array}$ & 81 & ASCE Library & Online \\
\hline
\end{tabular}




\begin{tabular}{|c|c|c|c|}
\hline $\begin{array}{l}\text { ASHRAE (Formerly the American } \\
\text { Society of Heating, Refrigerating } \\
\text { and Air Conditioning Engineers) }\end{array}$ & 12,125 & TechStreet & Online \\
\hline $\begin{array}{l}\text { ASME (American Society of } \\
\text { Mechanical Engineers) }\end{array}$ & 133 & TechStreet & Online \\
\hline $\begin{array}{l}\text { ASQ (American Society for } \\
\text { Quality) }\end{array}$ & 5 & & Print \\
\hline $\begin{array}{c}\text { ASSE (American Society of Safety } \\
\text { Engineers) }\end{array}$ & 1 & & Print \\
\hline $\begin{array}{l}\text { ASSE (American Society of Safety } \\
\text { Engineers) }\end{array}$ & 13 & TechStreet & Online \\
\hline $\begin{array}{l}\text { ASTM International (Formerly the } \\
\text { American Society of Testing and } \\
\text { Materials) }\end{array}$ & 13,337 & ASTM Engineering Digital Library & Online \\
\hline AWS (American Welding Society) & 8 & & Print \\
\hline AWS (American Welding Society) & 24 & TechStreet & Online \\
\hline $\begin{array}{l}\text { AWWA (American Water Works } \\
\text { Association) }\end{array}$ & 164 & TechStreet & Online \\
\hline $\begin{array}{l}\text { B11 Standards, Inc. (Formerly the } \\
\text { Association for Manufacturing } \\
\text { Technology) }\end{array}$ & 6 & TechStreet & Online \\
\hline $\begin{array}{l}\text { BHMA (Builders Hardware } \\
\text { Manufacturers Association) }\end{array}$ & 1 & TechStreet & Online \\
\hline BS (British Standards Institute) & 1 & & Print \\
\hline BSI (British Standards Institute) & 127 & TechStreet & Online \\
\hline $\begin{array}{l}\text { CAM-I (Consortium of Advanced } \\
\text { Management International) }\end{array}$ & 3 & & Print \\
\hline $\begin{array}{c}\text { CCITT (French: Comité } \\
\text { Consultatif International } \\
\text { Téléphonique et Télégraphique) } \\
\text { Now ITU-T (International } \\
\text { Telecommunication Union) }\end{array}$ & 2 & & Print \\
\hline $\begin{array}{l}\text { CGA (Compressed Gas } \\
\text { Association) }\end{array}$ & 2 & TechStreet & Online \\
\hline $\begin{array}{l}\text { CSA (Canadian Standards } \\
\text { Association) }\end{array}$ & 3 & TechStreet & Online \\
\hline $\begin{array}{c}\text { CTI (Cooling Technology } \\
\text { Institute) } \\
\end{array}$ & 1 & TechStreet & Online \\
\hline $\begin{array}{c}\text { DASMA (Door \& Access Systems } \\
\text { Manufacturers Association } \\
\text { International) } \\
\end{array}$ & 15 & DASMA Publications & Online \\
\hline DIN (German) & 2 & & Print \\
\hline $\begin{array}{c}\text { EIA (Electronic Industries } \\
\text { Alliance) }\end{array}$ & 7 & & Print \\
\hline FCI (Fluid Controls Institute) & 3 & TechStreet & Online \\
\hline $\begin{array}{l}\text { HFES (Human Factors and } \\
\text { Ergonomics Society) }\end{array}$ & 1 & TechStreet & Online \\
\hline HI (Hydraulic Institute) & 1 & TechStreet & Online \\
\hline
\end{tabular}




\begin{tabular}{|c|c|c|c|}
\hline $\begin{array}{l}\text { IAPMO (International Association } \\
\text { of Plumbing and Mechanical } \\
\text { Officials) }\end{array}$ & 2 & TechStreet & Online \\
\hline ICC (International Code Council) & 1 & & Print \\
\hline ICC (International Code Council) & 1 & TechStreet & Online \\
\hline $\begin{array}{l}\text { ICEA (Insulated Cable Engineers } \\
\text { Association) }\end{array}$ & 2 & & Print \\
\hline $\begin{array}{l}\text { IEC (International Electrotechnical } \\
\text { Commission) }\end{array}$ & 1 & & Print \\
\hline $\begin{array}{l}\text { IEC (International Electrotechnical } \\
\text { Commission) }\end{array}$ & 5 & TechStreet & Online \\
\hline $\begin{array}{l}\text { IEEE (Formerly the Institute of } \\
\text { Electrical and Electronics } \\
\text { Engineers) }\end{array}$ & 1,799 & IEEE Xplore & Online \\
\hline $\begin{array}{l}\text { IES (Illuminating Engineering } \\
\text { Society of North America) }\end{array}$ & 3 & & Print \\
\hline $\begin{array}{l}\text { IETF (Internet Engineering Task } \\
\text { Force) }\end{array}$ & 7,305 & IETF (RFC) Online & Online \\
\hline Iowa Code & 16 & Iowa Legislature & Online \\
\hline IPC ( Institute of Printed Circuits) & 25 & & Print \\
\hline $\begin{array}{l}\text { ISA (Instrumentation, Systems, } \\
\text { and Automation Society) }\end{array}$ & 21 & & Print \\
\hline $\begin{array}{l}\text { ISDSI (Insulated Steel Door } \\
\text { Systems Institute) }\end{array}$ & 3 & & Print \\
\hline $\begin{array}{c}\text { ISEA (International Safety } \\
\text { Equipment Association) }\end{array}$ & 3 & TechStreet & Online \\
\hline $\begin{array}{l}\text { ISO (International Organization for } \\
\text { Standardization) }\end{array}$ & 20 & & Print \\
\hline $\begin{array}{l}\text { ISO (International Organization for } \\
\text { Standardization) }\end{array}$ & 94 & TechStreet & Online \\
\hline $\begin{array}{l}\text { IWCA (International Window } \\
\text { Cleaning Association) }\end{array}$ & 1 & & Print \\
\hline JIS (JAPANESE) & 1 & & Print \\
\hline LIA (Laser Institute of America) & 1 & TechStreet & Online \\
\hline $\begin{array}{c}\text { MDC (M Technology Association } \\
\text { Division of ANSI) }\end{array}$ & 3 & & Print \\
\hline $\begin{array}{l}\text { MIL (Military Specifications and } \\
\text { Standards) }\end{array}$ & 6 & TechStreet & Online \\
\hline $\begin{array}{l}\text { NAPM (National Association of } \\
\text { Purchasing Management) }\end{array}$ & 7 & & Print \\
\hline $\begin{array}{c}\text { NCSL International (National } \\
\text { Conference of Standards } \\
\text { Laboratories) }\end{array}$ & 2 & & Print \\
\hline $\begin{array}{l}\text { NEMA (National Electrical } \\
\text { Manufacturers Association) }\end{array}$ & 5 & & Print \\
\hline $\begin{array}{l}\text { NFPA(Fire) (National Fire } \\
\text { Protection Association) }\end{array}$ & 354 & National Fire Code Subscription Service & Online \\
\hline
\end{tabular}




\begin{tabular}{|c|c|c|c|}
\hline $\begin{array}{l}\text { NFPA(Fluid) (National Fluid } \\
\text { Power Association) }\end{array}$ & 13 & TechStreet & Online \\
\hline $\begin{array}{c}\text { NFSA (National Fire Sprinkler } \\
\text { Association) }\end{array}$ & 2 & & Print \\
\hline NGV (Natural Gas Vehicle) & 1 & & Print \\
\hline $\begin{array}{l}\text { NISO (National Information } \\
\text { Standards Organization) }\end{array}$ & 49 & NISO Connects & Online \\
\hline $\begin{array}{c}\text { PIMA (Paper Industry } \\
\text { Management Association) }\end{array}$ & 10 & & Print \\
\hline QPL (Qualified Products List) & 1 & TechStreet & Online \\
\hline $\begin{array}{c}\text { RIA (Robotic Industries } \\
\text { Association) }\end{array}$ & 4 & TechStreet & Online \\
\hline $\begin{array}{l}\text { SAAMI (Sporting Arms and } \\
\text { Ammunition Manufacturers' } \\
\text { Institute) }\end{array}$ & 4 & & Print \\
\hline $\begin{array}{l}\text { SAE International (Formerly the } \\
\text { Society of Automotive Engineers) }\end{array}$ & 33 & & Print \\
\hline $\begin{array}{c}\text { SCTE (Society of Cable } \\
\text { Telecommunications Engineers) }\end{array}$ & 2 & TechStreet & Online \\
\hline $\begin{array}{c}\text { SIA (Security Industry } \\
\text { Association) }\end{array}$ & 1 & & Print \\
\hline $\begin{array}{l}\text { SMA (Screen Manufacturers } \\
\text { Association) }\end{array}$ & 4 & & Print \\
\hline $\begin{array}{l}\text { SMPTE (Society of Motion Picture } \\
\text { and Television Engineers) }\end{array}$ & 19 & & Print \\
\hline $\begin{array}{l}\text { SMPTE (Society of Motion Picture } \\
\text { and Television Engineers) }\end{array}$ & 1 & TechStreet & Online \\
\hline $\begin{array}{l}\text { SPI (Society of the Plastics } \\
\text { Industry) }\end{array}$ & 4 & TechStreet & Online \\
\hline $\begin{array}{l}\text { TIA (Telecommunications } \\
\text { Industries Association) }\end{array}$ & 10 & & Print \\
\hline US Code of Federal Regulations & 50 & US Government Printing Office & Online \\
\hline US Department of Defense & 82,000 & ASSIST & Online \\
\hline $\begin{array}{l}\text { VITA (VMEbus International } \\
\text { Trade Association) }\end{array}$ & 6 & & Print \\
\hline $\begin{array}{l}\text { VRCI (Variable Resistive } \\
\text { Components Institute) }\end{array}$ & 1 & & Print \\
\hline $\begin{array}{c}\text { X9 (Accredited Standards } \\
\text { Committee X9 Incorporated) } \\
\end{array}$ & 7 & TechStreet & Online \\
\hline Total Standards Available & 118,801 & & \\
\hline
\end{tabular}

Table 1: Agencies/Organizations' Standards Available at the University of Iowa

Purchasing standards can be an expensive endeavor so the library purchases new standards on an ondemand basis. Only standards that are relevant to research being conducted at the University of Iowa are collected. Due to this on-demand purchasing model, the library strives to make the turnaround time from when the standard is requested to when it is available to be around 1-2 business days. 
With the increase in access to Standards, it was now time to provide instruction on how to use and access these Standards.

\section{Standards in the Classroom}

Teaching standards through their curriculum is vitally important. Many employers prefer to hire graduates that are familiar with standards, but many students have little or no exposure to them through their course of study. ${ }^{2,3}$

In the College of Engineering at the University of Iowa, the library is seeing standards being used more and more in the classroom. One example is that over the last three semesters, the Engineering Librarian has been invited into a required class for Industrial Engineers titled "Process Engineering." During this course, the students are required to thoroughly review a standard of interest. The Librarian visited each class to provide instruction on the basics of standards, what they are used for, and how to find and access them. There have been several other courses using standards over the last couple years and hopefully this number will increase as instructors learn about these specialized resources being readily available through the Library.

\section{Conclusion}

The Lichtenberger Engineering Library has made great strides over the last couple of years to improve access and education on standards but there is still room for improvement. The library hopes to continue on increasing accessibility, especially electronic access, to a diverse variety of standards so that all departments and centers served by the library will have all materials that they need.

Education and outreach related to standards currently available and how they may be used will be a key focus for library staff in the future. The Library will work to promote the importance of standards in the curriculum. Knowledge of how to access and use standards will be a great asset to current students as they go out into the workplace and become professional engineers.

\section{Bibliography}

1. Subramanyam, Kirshna. 1981 Chapter 8: Standards and Specifications. Scientific and Technical Information Resources. Londan: CRC Press, p. 132.

2. Calvelli-Gaylor, E. 1984. Educational Needs. Mechanical Engineering 106(4): 52-55. 
3. Forbes, R.E \& Emplaincourt, M.C. 2003. Engineering standards and product liability. In: Proceedings of the American Society for Engineering Education Annual Conference. [Online]. Available: \{http://web.archive.org/web/20060827190911/http://www.asee.org/acPapers/2003-2046_Final.pdf\} [27 August 2014].

4. Mathews, B.S. 2006. The role of industry standards: an overview of the top engineering schools' libraries. Issues in Science and Technology Librarianship Spring 2006. DOI:10.5062/F48C9T6D

5. Pellack, L.J. 2005. Industry standards in ARL libraries: electronic and on-demand. Collection Building 24(1): 20-28.

6. Taylor, D. 1999. Standards collection development in an academic library. Collection Building 18(4): 148 - 152. 